Article

\title{
Monitoring and Assessment of Protected Areas' Management Capacities in the Republic of Serbia
}

\author{
Nikola Banjac ${ }^{1,2}$, Rado Maksimović ${ }^{2}\left(\mathbb{D}\right.$, Katarina Dragaš ${ }^{3}$ and Jelena Ivetić ${ }^{2, * \mathbb{C}}$ \\ 1 Assembly of the Autonomous Province of Vojvodina, Novi Sad 21000, Serbia; banjacn@gmail.com \\ 2 Faculty of Technical Sciences, University of Novi Sad, Novi Sad 21000, Serbia; rado@uns.ac.rs \\ 3 Institute for Nature Conservation of Vojvodina Province, Novi Sad 21000, Serbia; \\ katarina.dragas@gmail.com \\ * Correspondence: jelenaivetic@uns.ac.rs
}

Received: 31 December 2018; Accepted: 22 January 2019; Published: 28 January 2019

\begin{abstract}
The necessity to measure the effectiveness of the management of protected areas has been widely recognized. This paper aims to show a realistic state of affairs in protected area management in the Republic of Serbia on the basis of the results of managers' monitoring and their obligations stipulated by law. It will also answer questions on which form of management is optimal, by means of a proposed assessment model. The research has been performed on a sample of 30 sensu stricto protected areas, managed by 21 different managers. For the purpose of ranking and comparing the degree of protected area management effectiveness, the use of a normalized aggregate function (scoring) has been introduced. Results show that about half of the analyzed protected areas have no adequate management in terms of legally prescribed management criteria, as well as that management effectiveness is related to several external factors. The authors conclude that meeting all criteria stipulated by law, and the existence of professional staff represent fundamental factors for the effective management of protected areas.
\end{abstract}

Keywords: protected areas; nature conservation; management effectiveness; criteria stipulated by law; professional staff; Republic of Serbia

\section{Introduction}

Today we witness a crisis of biological diversity due to dramatic changes in the environment, primarily as a result of direct or indirect human activity. Reduction of biodiversity has, in a great measure, affected the following three aspects-genetics, species, and ecosystems. One of the ways to try to conserve biodiversity is to place parts of nature under protection. In recent decades, a lot has been done in the field of nature conservation, with the result that by 2014 some 209,000 areas were protected worldwide. This represents $15.4 \%$ of all terrestrial and freshwater ecosystems, as well as $3.4 \%$ of oceans [1].

Even though there has been an increase in the number of protected areas worldwide [2], the loss of biodiversity is still in progress [2-4]. One of the reasons for this is the fact that numerous protected areas are not managed adequately [5,6]. It is precisely for this reason that many protected areas are in danger of losing the values for which they had been primarily placed under protection [7].

The necessity to measure the effectiveness of protected area management has been widely recognized internationally since the sole action of declaring an area as protected does not necessarily result in the successful implementation of protective measures, neither in developed nor in developing countries [8-10]. At present, over 9000 assessments of protected areas' management effectiveness have been conducted [11], mainly through Management Effectiveness Tracking Tool [12], and the Rapid Assessment and Prioritization of Protected Areas Management [13]. Nevertheless, previous analyses 
have shown that in as few as $24 \%$ of assessments, the protected area management was good, $36 \%$ had basic management, $27 \%$ had large management deficiencies, while $13 \%$ of protected areas lacked management altogether [14].

In the context of protected areas, Cifuentes et al. [15] (p. 11) define management as, "The combination of actions with a legal, political, administrative, research, planning, protective, coordinating, interpretative or educational character, that results in the better use and permanence of a protected area, and the accomplishment of its objectives." International Union for Conservation of Nature (IUCN), i.e., World Commission on Protected Areas (WCPA), defines the management effectiveness assessment as "...the assessment of how well protected areas are being managed-primarily the extent to which management is protecting values and achieving goals and objectives" [16] (p. 1).

A significant threat to protected areas is that certain protected areas have only weak regulations and enforcement capacity [17]. These protected areas are referred to as 'paper parks' [18] since it is considered that they are protected 'only on paper', and they often fail to accomplish the goals of nature conservation due to the lack of legal and financial support $[14,19,20]$.

From this fact, a necessity arises to comprehend the objective state of management capacities to create a realistic picture of the state of management potential. Without such analysis, it is impossible, in a strategic sense, to create strategies for the further development of protected area management. Thus, the aim of this paper is to show a realistic state of affairs in protected area management in the Republic of Serbia on the basis of the results of managers' monitoring and their obligations stipulated by law, and to answer the questions as to which form of managementis optimal based on the existing ones and considering the analyzed variables. The relevance of studying this subject arises from ascertaining that three out of the five most common threatening factors belong to deficiencies in management and policy, including inadequate legislation, poor administrative (management) practices, as well as lack of funding and staff, all of which are much more prevalent than external threatening factors [21].

\section{Situation in the Republic of Serbia}

The Republic of Serbia is located in southeastern Europe with a surface area of 8,836,100 ha. The total surface area of protected areas occupies $5.91 \%$ of the country's territory $(522,120$ ha) [22]. In Serbia, the system of conservation of nature is defined in detail in the Law on Nature Conservation, which fully prescribes the protection and conservation of nature, biological, geological, and landscape diversity [23]. The Law contains provisions relating to the management model, manager selection, drafting of founding documents, plans, programs and management measures, funding models, and type and composition of the governing body.

According to Article 67 of the Law, it is stipulated that protected area management is an activity of public interest, and that a protected area can be managed by a legal entity (i.e., manager) that meets professional, human resources, and organizational conditions for the activities of conservation, improvement, and promotion of natural and other values, and the sustainable use of protected areas. Whether these conditions are met is established by the Ministry, i.e., the body in charge for the affairs of environment conservation of an autonomous province or of local self-government, within the process of preparing the act of declaring protected areas.

The Law (Article 68) strictly prescribes the manager's obligations regarding protected area management. Some of these obligations include guarding the protected area and implementing the prescribed conservation regimes; adopting the management plan and the rulebook on interior order and guarding specified by the decision on conservation; adopting the rulebook on the charges act, etc. Unfortunately, the Law does not prescribe the body charged with monitoring managers' functions, resulting thereby in no control regarding meeting the obligations stipulated by law for protected area managers. Manager obligations cannot be met if human resource prerequisites are not met, i.e., if there are no fully trained and professional staff, as well as a thoroughly elaborated 
operational program with realization capabilities for numerous activities, for the purpose of protected area sustainable management.

Regarding the analysis of the work of legal entities operating in the field of protected area management in the Republic of Serbia, from the aspect of management science, one should take into account specific data, statistics, analyses, trends, predictions, forecasts, conclusions or statements of experts, or other kinds of evidence to serve as indicators of current or expected events in relevant sectors [24]. Since the effectiveness assessment of protected area management is a relatively new concept in Serbia, so far only two studies have been conducted. The first one was 'Rapid Assessment and Prioritization of Protected Area Management' (RAPPAM) (see [25]), by the Ministry of Environment and Spatial Planning in cooperation with WWF, in 2009. The study was done based on responses by the protected areas' representatives, regarding planning, investing, and management process. Stated positive sides are as follows: good planning, legal security, and infrastructure. Stated weak points are the lack of finances and human resources. The level of cooperation with local communities is, in most areas, relatively low, particularly in terms of joint planning and decision making. The results of scientific research are often inaccessible, whereas in some cases they do not correspond to the area's requirements [26].

According to the Law on Nature Conservation in the Republic of Serbia, the Ministry is obliged to, once every five years, submit a Report to the Government on the State of Nature in the Republic of Serbia, prepared by the authorized expert institutions. In this manner, after more than 5 years following the RAPPAM, a 'Report on the State of Nature for the Period 2010-2014' was prepared, based on similar questionnaires. This is the second and most recent evaluation of protected area managers' performance done so far.

Nevertheless, in performing the analysis of the protected areas managerial capacities, it is primarily necessary to do analysis as to which protected areas meet the criteria stipulated by law regarding management, and which fail to do so, and only then proceed with the next stage of research-management effectiveness assessment. Effectiveness assessment is the following step of the analysis, naturally under the assumption that all legal prerequisites have been previously met regarding the protected area management. The authors of this paper have, therefore, postulated two research objectives:

(1) Monitoring - to analyze if and to what extent legal entities meet the criteria for performing tasks of protected area management for the period 2010-2014;

(2) Assessment- - to assess the management effectiveness based on the existing parameters, as well as to explore the correlation between the management effectiveness on one side, and the external properties of the protected areas on the other side.

\section{Methods and Data Analysis}

The paper is based on data processed in the research conducted on the territory of the Republic of Serbia for the purpose of drafting the Report on the State of Nature in the Republic of Serbia for the Period 2010-2014 (see [27]). The research was conducted using the data provided by protected area managers, on the basis of a questionnaire. The questionnaire was created to respond to the needs of various target groups of managers, (bio-)geographic region and protected area category [28]. Moreover, the questionnaire has been standardized by the authorized expert institutions, harmonized with the regulations of the Republic of Serbia [23] (and indirectly with EU regulations that were incorporated into the Law [23]), whereas validation has been obtained by National Assembly of the Republic of Serbia. The research was conducted in the period of February to May 2015. For the purpose of this paper, the data from two domains were processed: (1) General Data on the Protected Area's Manager and (2) Management Acts. The collected data was first subjected to descriptive data analysis. After that, a model for the management effectiveness assessment was constructed and applied to the sampled protected areas. Finally, the relationship between specified external factors and the assessment results was examined. The conceptual framework of the research is given in Figure 1. 


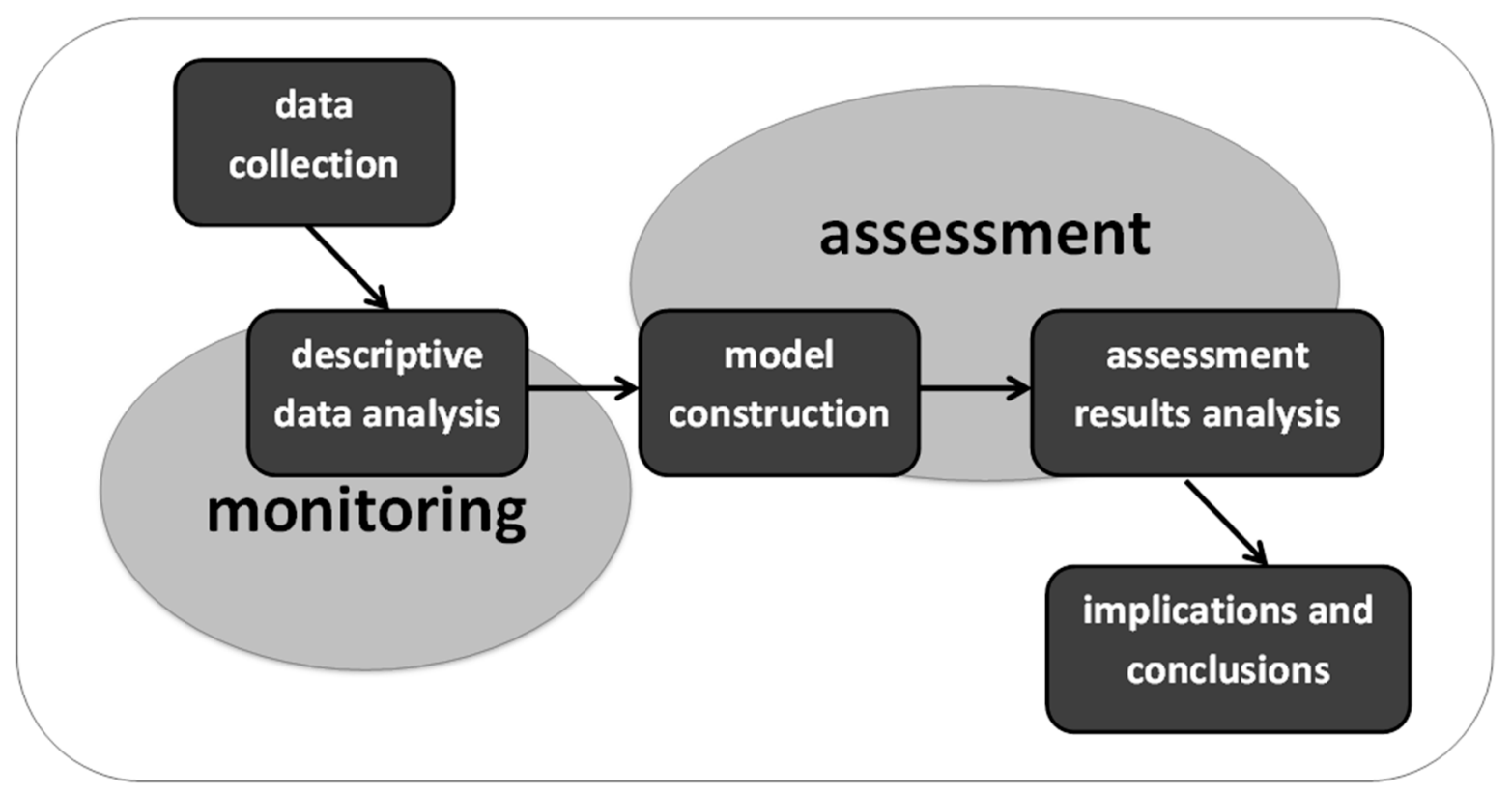

Figure 1. Conceptual framework.

\subsection{Study Site Selection}

Bearing in mind that the manner of management and the scope of obligations of the manager greatly differ depending on the size and type of the natural resource [29], a division has been made to allow results to be more easily processed and displayed. Protected areas established for the purpose of conserving the ecological and geological values are named protected areas sensu stricto (i.e., in a narrow or strict sense) [27]. These are natural entities whose surface exceeds 100 ha. Protected parks, conserved for the reason of created horticultural values, mainly located within urban areas and generally smaller than 100 ha, have been singled out. The singular protected areas, namely protected trees, have also been singled out.

The research has been performed on a sample of 30 sensu stricto protected areas (Figure 2), managed by 21 different managers. Some individual managers often administrate several protected areas (see Appendix A, Table A1). Their total surface area is 135,368 ha or $30.43 \%$ of the entire sensu stricto protected areas in the Republic of Serbia. These protected areas are located within the Pannonian biogeographic region, which administratively corresponds to the Autonomous Province of Vojvodina.

The majority of these protected areas were declared between 1993 and 2002, on the basis of solutions offered by the Law on Environment Conservation from 1991, from which the 2009 and 2016 Law on Nature Conservation also originated. Declaration acts have been revised and harmonized in accordance with the newest legislation. Researched sensu stricto areas belong to various protected areas categories (six of eight categories, according to national categorization). These are as follows: special nature reserves, national parks, protected habitats, landscapes with outstanding features, nature parks. Comparison of these national categories with the IUCN categories has indicated that the protected area categories are not entirely compatible [30] (Table 1). Conservation regimes have been established in all the listed categories [31].

The majority of the analyzed conserved habitats, which represent the largest protected areas, can be found in hilly areas and in the wide floodplains of Danube and Sava rivers basins. In areas favorable for the development of agriculture, protected areas are significantly smaller and often comprise a larger number of patches. Only four protected areas are larger than 10,000 ha. There are 11 protected areas whose size is between 1000 ha and 10,000 ha, whereas the greatest number of protected areas, 15 of them, are between 100 and 1000 ha in size. 


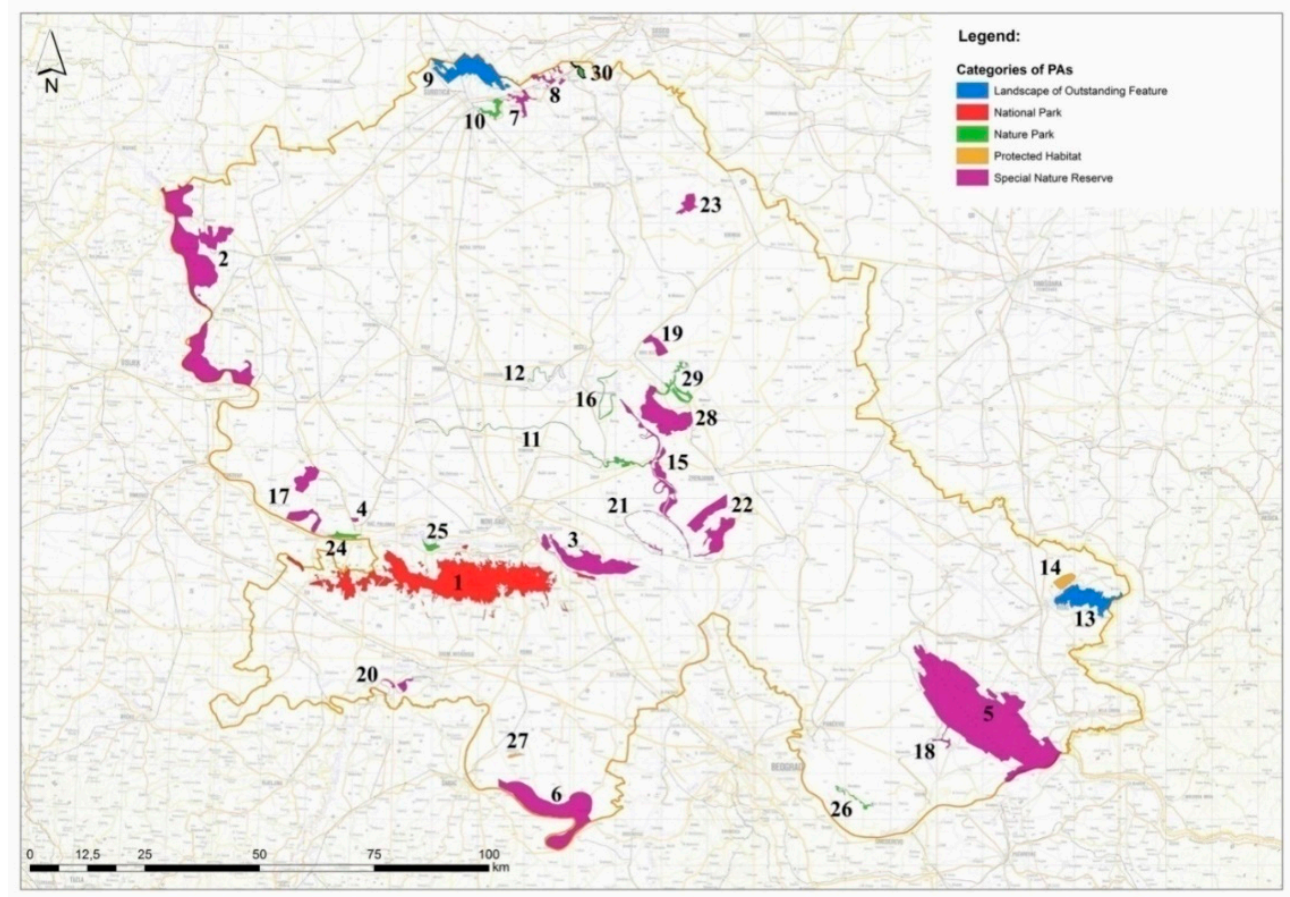

Figure 2. Map of the analyzed protected areas in the Autonomous Province of Vojvodina. Source: Database of the Provincial Institute for Nature Conservation and topographic map (Military Geographical Institute, TM 300000), processed in ESRI ArcGIS 10.3.1. The numbers correspond to protected areas as listed in Appendix A, Table A1.

Table 1. Comparison of national and IUCN (International Union for Conservation of Nature) protected areas categorization system (harmonized according to [30]).

\begin{tabular}{ccc}
\hline National Category & Primary Purposes & IUCN Category \\
\hline special nature reserves & $\begin{array}{c}\text { scientific research, conservation of biodiversity, } \\
\text { protection of species, habitats and ecosystems } \\
\text { scientific research, conservation of biodiversity, } \\
\text { tourism and recreation, } \\
\text { sustainable use of resources } \\
\text { protected habitats }\end{array}$ & $\begin{array}{c}\text { IV } \\
\text { scientific research, conservation of biodiversity, } \\
\text { protection of species and habitats } \\
\text { sustainable use of resources, conservation of } \\
\text { cultural heritage and of spatially limited } \\
\text { geo-diverse and landscape locality }\end{array}$ \\
landscapes with & $\begin{array}{c}\text { sustainable use of natural resources, landscape } \\
\text { and cultural heritage conservation }\end{array}$ & IV \\
nature parks & V & VI
\end{tabular}

There are various types of habitats within the examined protected areas. Among them, most prominent being euro-siberian steppe woods with Quercus spp., subcontinental peri-pannonic scrub, pannonic sands, loess steppes, sand steppes, salt marshes, salt steppes, and saline grasslands, as well as numerous wetland complexes [32]. In the Pannonian biogeographic region of the Republic of Serbia, there are approximately 494 species of vertebrates, out of which 360 species are strictly protected [33]. There are 4092 invertebrates, out of which 73 species are strictly protected. The total number of plant species is approximately 1750, out of which 149 species are strictly protected [33].

The Pannonian biogeographic region of the Republic of Serbia has significantly altered natural characteristics due to anthropogenic activities, greatly pressurizing the functionality of the ecosystems and decreasing their resistance to other influences. Some of the more significant threatening factors are alterations of purpose or manner of land usage. Impact on ecosystems is through 
conversion, degradation, and spatial connection alterations, with fragmentation consequences, erosion, compression, eutrophication, etc. According to [27], as many as $90 \%$ of protected areas experience unfavorable changes of species composition due to succession.

\subsection{Variable Selection}

The relevant variables for monitoring and assessment of management capacities are presented in Table 2. They are classified into two groups and three levels, according to their obligatory status and assumed importance.

Group I-variables representing the foundation for manager's functioning: existence of legal acts further stipulating acts to be adopted by the manager; manager's human resource capacity;

Group II-variables representing the implementation of legally prescribed obligations in the field.

Table 2. Selected Variables.

\begin{tabular}{ccc}
\hline & Group I & Group II \\
\hline Level 1 & Level 2 & Level 3 \\
\hline $\begin{array}{c}\text { Management plan } \\
\text { Professional staff }\end{array}$ & $\begin{array}{c}\text { Annual management plan } \\
\text { Rulebook of charges } \\
\text { Ranger service }\end{array}$ & $\begin{array}{c}\text { Number of realized and started projects } \\
\text { for 2010-2014 } \\
\text { Species monitoring } \\
\text { and guarding }\end{array}$ \\
& $\begin{array}{c}\text { Educational and promotional programs } \\
\text { Education on EU integration in the field } \\
\text { of nature conservation }\end{array}$ \\
& $\begin{array}{c}\text { Administrative e-database } \\
\text { Biodiversity e-database } \\
\text { Tourist paths }\end{array}$ \\
& $\begin{array}{c}\text { Visitors' centers } \\
\end{array}$ & Organized tours for visitors \\
\hline
\end{tabular}

First group variables (Level 1 and Level 2) are as follows.

Protected area management plan determines the manner to conduct conservation, usage and management of the protected area, guidelines and priorities for protection and conservation of natural values of protected areas, as well as to give development guidelines, fully observing the needs of the local population. The plan is adopted for a period of 10 years and represents a strategic management plan for every protected area [34].

Annual management plan is a document which operationally implements the strategy envisaged in the Management plan.

Rulebook of charges represents a binding legal document adopted by the manager of a protected area. It defines the fee to be paid on various grounds by the users of the protected area (tourist contents, hospitality, usage of wild flora and fauna, usage of motor vehicles, etc.). These funds represent the manager's legal income to be allocated to the purpose of protected area conservation and improvement.

Rulebook on protected area's interior order and guarding is a legally prescribed document obligatory for every protected area manager. This document determines the organization of ranger service, guarding of the protected area, equipment, and the means necessary for guarding and maintenance, and behavior and movement of visitors and users of the protected area.

Professional staff within the protected area manager's organization presumes that the manager, as a legal entity, must be capable of performing conservation, improvement, promotion, and sustainable development of the protected area [35]. The Rulebook on the conditions to be met by protected area managers stipulates that manager must have an organized service composed of at least one employee for nature conservation, one employee for project management, and one employee for legal and economic affairs for the purpose of protected area manager. 
Ranger service within the protected area presumes that the protected area manager must have rangers employed whose role is to maintain internal order within the protected area, in accordance with the rulebook on internal procedures and guard services. The manager of the area is obliged to provide at least one ranger per a 3000 ha surface.

The above-listed variables represent the basic legal presumptions to be fulfilled by protected area managers to qualify for assessment of their effectiveness. The management plan should represent the basic management plan of a protected area, as well as the indispensable management element. Moreover, one can hardly discuss conservation of biodiversity if the manager has no professional staff and ranger service, which is why these three variables are considered to be condicio sine qua non and are deemed as Level 1 variables.

Level 2 variables, namely Annual management plan, Rulebook of charges and the Rulebook on interior order and guarding are legal documents that can be adopted during the protected area's operation period, i.e., it is legally possible, although with some difficulties, to have a functioning protected area without these documents.

Second group/Level 3 variables indicated in Table 3 represent activities to be performed by protected area managers in accordance with the law and bylaws, i.e., these are the primary operational activities of conservation and improvement of protected areas, to be conducted in the field.

Table 3. Descriptive statistics of protected areas.

\begin{tabular}{cc}
\hline Property & Frequency (\%) \\
\hline Minimal conditions stipulated by law (Level 1) & \\
Management plan & $26(86.67 \%)$ \\
Professional staff (minimum three employees) & $17(56.67 \%)$ \\
Ranger service (minimum three employees) & $19(63.33 \%)$ \\
\hline Other conditions stipulated by law (Level 2) & \\
Annual management plan (2010-14) & $18(60.00 \%)$ \\
Rulebook of charges & $21(70.00 \%)$ \\
Rulebook on interior order and guarding & $27(90.00 \%)$ \\
\hline All conditions stipulated by law (Level 1 + Level 2) & $\mathbf{1 3}(\mathbf{4 3 . 3 3 \% )}$ \\
\hline Additional variables (Level 3) & \\
Number of realized and started projects (2010-14) & $4(0-16) *$ \\
Monitoring of species & $26(86.67 \%)$ \\
Educational and promotional programs & $26(86.67 \%)$ \\
EU integration in the field of nature conservation & $19(63.33 \%)$ \\
Administrative e-database & $22(73.33 \%)$ \\
Biodiversity e-database & $14(46.67 \%)$ \\
Tourist paths & $23(76.67 \%)$ \\
Visitors' center & $16(53.33 \%)$ \\
Organized tours & $18(60.00 \%)$ \\
\hline * median (range). & \\
\hline
\end{tabular}

Projects enable financing of the activities for the purpose of protected area's biodiversity conservation. Moreover, the number of projects represents an indicator of the manager's and professional service's capacity to attract funds and improve conservation. Bearing in mind that funds allocated by the state or local self-governments are often insufficient, this aspect of funding is additionally important for the conservation and improvement of the protected area.

Participating in education on EU integration in the field of nature conservation. Within the last couple of years, significant nature protection effort in the Republic of Serbia has been aimed at meeting the obligations of the EU accession process. Apart from the implementation of international conventions, directives, and binding guidelines into domestic legislation, it is necessary to increase the number of protected areas, expand the national ecological network, and establish the Natura 2000 
ecological network. This represents a great challenge and obligation, which is why managers should familiarize and educate as many employees as possible.

Monitoring of species, i.e., planned, systematic, and continuous monitoring of the state of nature, i.e., parts of the biological, geological, and landscape diversity, as a part of an integral system of monitoring the state of the environment within space and time [36], is of immeasurable value for effective management of protected areas. In case there is no such monitoring, there is no possibility to follow the effects of conservation of nature in the field. Monitoring is directly connected with the databases, i.e., best effects would be achieved if the collected data were immediately entered into the e-databases, where their processing would take place as well.

Educational and promotional programs are, legally speaking (Article 68 of the Law on Nature Conservation), one of the primary activities of the protected area's manager. Protected areas have strong educational aspects, and those should be places where the young are educated and brought up in the spirit of preserving biodiversity. This is the task to be carried out by the professional staff of the protected area manager.

Tourist paths, visitors' centers, organized tours for visitors are within the field of tourism [37]. Tourism management within the protected area is hugely important since tourism in nature can be sustainable only if natural values are preserved. It is important to learn about the development of tourism, visitors' behavior and interests, to better plan the facilities and activities within the protected area and define the correct management strategies [38].

E-databases. It is preferred that each protected area develops and improves an e-database on its key natural values, data on protection activities carried-out conservation, and other activities on their territory, all for the purpose of monitoring and evaluating and proposing improvement measures. Pursuant to the Article 50 of the Law on Nature Conservation, the Registry of protected areas represents an e-database on protected areas, etc. Comprehensive data is required even across the administrative borders, which is why it is important to ensure the flow of data between the organizations [39] in the area of conservation of nature.

These are the indispensable elements based on which one can judge whether a protected area is managed correctly or not [40]. It is also important to note that one of the more significant factors for selection of these variables is that all the listed elements are measurable and easily checked.

To better evaluate management effectiveness, additional properties have been analyzed as well: the protected area's surface area, the percentage of professional staff out of the total number of employees, number of rangers per surface area, level of protection according to IUCN and national categorization (see Table 1); primary activities (nature conservation or other) and manager's organizational type (public companies, NGO, private companies, state institutions). These variables are referred to as external factors since they were not included in the assessment model.

\subsection{Empirical Analysis}

For the purpose of ranking and comparing the degree of protected area management effectiveness, a normed aggregate function $S$ (scoring) has been introduced, allocating to each observed protected area a numerical value from 0 to 100 . The assessment model (1) was built as a linear combination of the following variables.

- $\quad \mathrm{A}_{1}: 1$ - if the Protected area management plan existed; 0—otherwise;

- $\mathrm{A}_{2}$ : 1-if Professional staff consisted of at least three employees; 0 -otherwise;

- $\quad \mathrm{A}_{3}: 1$-if the Ranger service consisted of at least three employees; 0 -otherwise;

- $\mathrm{B}_{1}$ : number of Annual management plans in 2010-2014 period, divided by five;

- $\mathrm{B}_{2}: 1$-if the Rulebook of charges existed; 0-otherwise;

- $\quad \mathrm{B}_{3}: 1$ - if the Rulebook on protected area's interior order and guarding existed; 0 —otherwise 
- $C_{1}$ : number of projects classified into five categories (values $0-4$ ). Value 0 corresponds to 0 started or completed projects in 2010-2014 period, whereas values 1 to 4 correspond to quartile distribution of numbers of started or completed projects;

- $\mathrm{C}_{2}: 1$-if Monitoring of species was performed; 0—otherwise;

- $C_{3}: 1$-if Participation in the education of EU integration in the field of nature conservation was performed; 0 - otherwise;

- $\quad \mathrm{C}_{4}: 1$-if Educational and promotional programs were performed; 0—otherwise;

- $\quad \mathrm{C}_{5}: 1$-if Administrative e-database existed; 0—otherwise;

- $\mathrm{C}_{6}: 1$ - if Biodiversity e-database existed; 0 -otherwise;

- $\quad \mathrm{C}_{7}: 1$-if Tourist paths existed; 0 -otherwise;

- $\mathrm{C}_{8}: 1$-if Visitors' center existed; 0-otherwise;

- $C_{9}$ : 1—if organized tours for visitors existed; 0 - otherwise.

$$
S=\left(5 \sum_{i=1}^{3} A_{i}+3 \sum_{j=1}^{3} B_{j}+\sum_{k=1}^{9} C_{k}\right) * 100 / 36
$$

In Equation (1), weights 5/3/1 are allocated to variables belonging to levels 1/2/3 (see Table 2) to represent their assumed relevance in the model.

Empirical analysis of the results encompasses the descriptive and non-parametric comparative statistical methods, as well as graphical rendering of the results. The data has been statistically processed through the Statistica 13.0 program. In comparative tests, differences corresponding to the $p$-value less or equal than 0.05 were considered statistically significant.

\section{Results}

Primary characteristics of the observed properties, based on which the evaluation of protected area management effectiveness has been measured, are provided in Table 3, where one can see the portion of representation of the selected variables in the observed sample of 30 protected areas.

Table 3 indicates that none of the observed variables is universally represented, not even those representing minimal conditions. Out of Level 1 variables, most represented is the management plan (at $86.67 \%$ protected areas), whereas the least represented is the adequate professional staff of at least three employees (at 56.67\% protected areas). Out of Level 2 variables, i.e., other law-stipulated conditions, most widely represented is the Rulebook on interior order and guarding (at $90 \%$ of examined protected areas), whereas the Annual management plan for every five years (from 2010 to 2014), was present with only $60 \%$ of examined protected areas. Nevertheless, it is worth mentioning that the percentage of representation of annual management plan from 2010 to 2014 is increasing, so that in 2010 and in 2011 only $63.33 \%$ of protected areas had management plan, in 2012 as many as $73.33 \%$, in 2013 precisely $76.67 \%$, whereas in 2014 the figure is as much as $90 \%$. In total, all six conditions stipulated by law (Level $1+$ Level 2 ) were met by only 13 of the evaluated 30 protected areas, i.e., $43.33 \%$.

When it comes to additional variables of management effectiveness, Level 3 properties, the most frequently present are species monitoring and participating in educational programs and promotional events, both with $86.67 \%$, whereas the least frequent is the biodiversity e-database, represented with only $46.67 \%$ of the evaluated protected areas. The numerical property 'realized and started projects' exhibits great variation. While certain protected areas have more than 10 started projects, as many as five of them have none, resulting in the median of four started projects per year (less than one annually).

Following the calculation of the management effectiveness standardized numeric score, it is possible to rank the evaluated protected areas according to their degree of effectiveness, as well as to examine the impact of external factors on the quality of protected area management. A graph of all protected areas ranked according to their assigned score is provided in Appendix A, Figure A1. Two protected areas have a maximum score of $100 / 100$, meaning that they exhibit all examined effectiveness variables, whereas the lowest ranked protected area has a score 6/100. 
Correlation between the effectiveness management score and certain numeric properties of protected areas (surface area, percent of professional staff within the total number of employees, number of rangers per surface unit, level of conservation according to IUCN and national categorization) is examined with Spearman's rank correlation coefficient, in accordance with non-parametric nature of the majority of properties. Results are provided in Table 4, which contains five pairs of correlated variables. Statistical significance of the calculated Spearman's rank correlation coefficients has been confirmed with the corresponding $t$-test and shown with the value of $t$-statistics with $\mathrm{N}-2$ degrees of freedom, and the corresponding $p$-value.

Table 4. Correlation between effectiveness score $S$ and numeric properties of protected areas.

\begin{tabular}{ccccc}
\hline Variable Pairs & Valid Sample N & Spearman Coefficient R & $\mathbf{t}(\mathbf{N}-2)$ Statistics & $p$-Value \\
\hline S and surface & 30 & $0.4317^{*}$ & 2.5328 & 0.0172 \\
$S$ and \% of prof. staff & 30 & $0.3892^{*}$ & 2.2359 & 0.0335 \\
$S$ and No. of guards per ha & 28 & 0.1536 & 0.7927 & 0.4351 \\
S and IUCN category & 27 & 0.0123 & 0.0618 & 0.9512 \\
$S$ and national category & 30 & $0.3925^{*}$ & 2.2581 & 0.0319 \\
\hline
\end{tabular}

* significant at the 0.05 level.

Using Table 4, one establishes that there is a statistically significant positive correlation between the measured degree of effectiveness and the following properties: the surface of the protected area, the percentage of professional staff in the entire number of employees and the level of conservation determined on the basis of Serbian protected area categorization. No statistically significant correlation was found between the score of effectiveness and the number of guards per area unit, nor between the effectiveness score and the level of conservation determined through international IUCN categorization.

The impact of a manager's primary activity (binary division of activity: nature conservation/other) on the degree of management effectiveness is examined with Mann-Whitney $U$ test, the results are given in Table 5.

Table 5. Comparison of effectiveness scores of managers with various primary activities.

\begin{tabular}{cccccc}
\hline MW U-Test & $\begin{array}{c}\text { Sum of Ranks (Nature } \\
\text { Conservation, N = 6) }\end{array}$ & $\begin{array}{c}\text { Sum of Ranks } \\
(\text { Other, } \mathbf{N}=\mathbf{2 4})\end{array}$ & U-Statistics & Z-Statistics & $p$-Value \\
\hline$S$ & 82.00 & 383.00 & 61.00 & -0.5444 & 0.5862 \\
\hline
\end{tabular}

Analysis results in Table 5 show that the examined sample exhibited no statistically significant difference in the effectiveness degree between the management of the first and the second group of protected areas, i.e., in groups whose manager's primary activity is nature conservation, and whose primary activity is some other.

Finally, the impact of a manager's organizational type on the level of effectiveness has been examined with non-parametric Kruskal-Wallis ANOVA test. The test results, $\mathrm{H}(\mathrm{df}=3, \mathrm{~N}=30)$-statistics $=2.5404, p$-value $=0.4680$, indicate that based on the observed sample no statistically significant difference has been found between the scores of effectiveness in the four groups of protected areas managed by managers of various organizational types. Despite such results, graphic rendering of the effectiveness degree distribution in these four groups (Figure 3) suggests that the management effectiveness level is slightly better in public companies (PC) than in the other three groups (NGO, private companies $\mathrm{PR}$, state institutions SI), but the difference cannot be considered statistically significant due to the highly manifested minimum of the entire sample belonging to this group. 


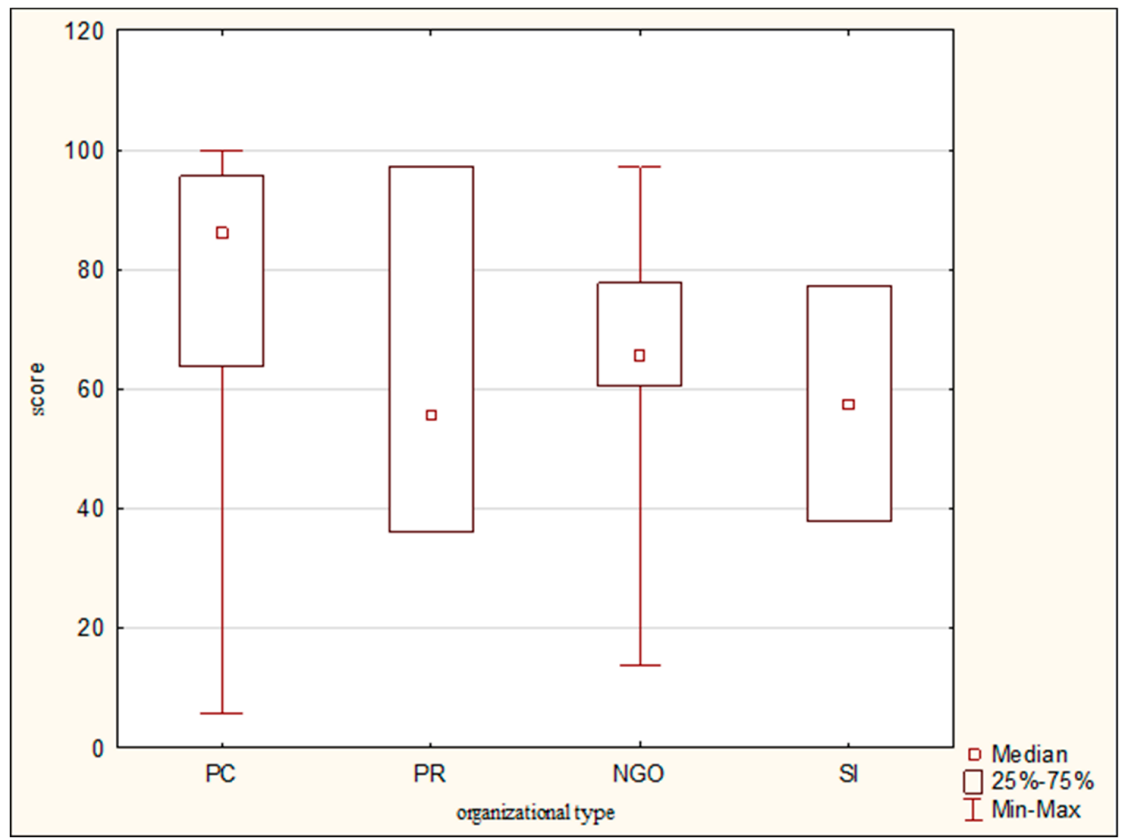

Figure 3. "Box and whiskers" plot of score distribution depending on the manager's organizational type.

As the final step in the assessment results analysis, performed to interrelate fundamental and implementation criteria, i.e., to emphasize the significance of Level 1 variables of the model, we compared effectiveness of implementation (measured by sum of $C_{k}$ variables, $\mathrm{k}=1, \ldots, 9$, i.e., sum of Level 3 variables) between two subsamples. The first one consists of 13 protected areas that met all three Level 1 criteria, whereas the second one consists of remaining 17. Mann-Whitney test results $(\mathrm{U}$-statistics $=35.5$, Z-statistics $=3.118, p$-value $=0.0018)$ indicate that there exists a highly significant difference between the effectiveness of the two groups in terms of implementation. Box-and-whiskers plot for two groups (Group 1-Level 1 criteria are met; Group 2-Level 1 criteria are not met) is given in Figure 4.

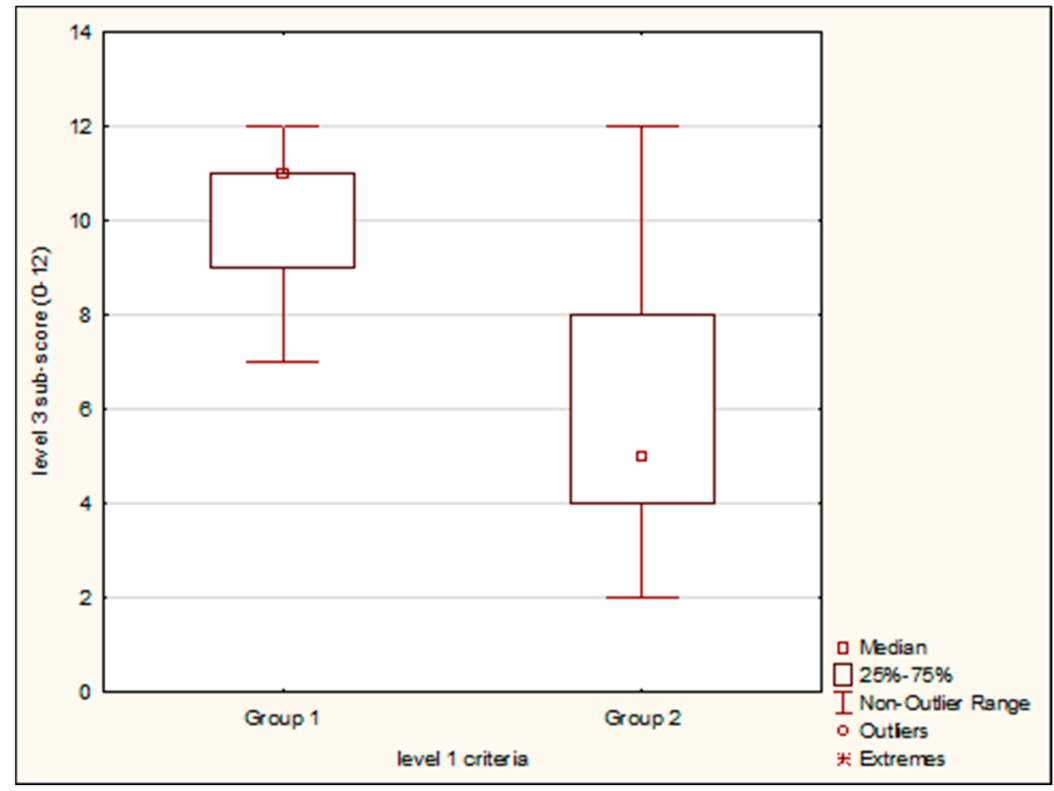

Figure 4. "Box and whiskers" plot of Level 3 sub-score distribution depending on the fulfillment of the Level 1 criteria. 


\section{Discussion}

Managing protected areas is a complex task of national and international public significance. Contemporary science dealing with protected area management is trying to answer which models of protected area management are the most suitable and the most effective. To provide these answers, the authors believe that first, it is necessary to analyze the fulfillment of criteria stipulated by law, which are mandatory to be performed by the protected area mangers, since this represents the fundamental and necessary minimum before any other analysis.

All the criteria stipulated by law are met by only $43.33 \%$ managers of the investigated protected areas. From this, one infers that it is from this group of managers that the best model of protected area management should be obtained. Furthermore, 56.67\% of protected areas do not meet some of the legally stipulated conditions, and, therefore, it would be necessary to revise the decisions on awarding certain protected area to individual managers. In certain cases, some deficiencies could be removed by setting additional deadlines for managers to harmonize their work with the stipulated norms. We believe that managers who cannot or do not wish to meet legally stipulated tasks regarding protected area management, should not be allowed to operate in this business at all. Protected area management must have its minimal conditions, i.e., standards in operating in this field of work and they should be completed and fulfilled. This represents an initial baseline of good management, and measuring the effectiveness and creation of the best possible management model is the upgraded superstructure of previously set standards.

As already stated, the first assessment of protected area management effectiveness in the Republic of Serbia was RAPPAM in 2009. In RAPPAM analysis took part as many as 10 managers, out of which five simultaneously participated in producing RAPPAM and the Report on the State of Nature for the Period 2010-2014. The data from the Report was also used for the purposes of this paper. The five managers who participated, are in charge of 12 protected areas. Out of those 12 protected areas, the analyzed legally prescribed management criteria were met by eight of the protected areas. Four protected areas do not meet these legal standards, which is why we believe they should not have been analyzed in the RAPPAM in first place since these managers simply do not meet legally stipulated criteria otherwise obligatory for managers. It would be useful to implement other internationally recognized assessment methods, such as Management Effectiveness Tracking Tool (METT) [12] and compare the obtained results.

Additional indicators were taken as means for assisting in the analysis of establishing protected area management effectiveness. Clear, measurable and agreed goals enable the assessment of effectiveness and identification of uncertainty in management practices and increase the protected areas management effectiveness [17]. The analysis shows that only two protected areas have all the examined effectiveness indicators (100/100, Appendix A, Figure A1), thereby implying the response regarding the model for good management.

Management effectiveness has been examined from the point of view of correlation between the scores of management effectiveness and certain external factors: surface area, percentage of professional staff, number of guards per surface unit, IUCN and national protected area categorization. The analyses indicate that a significant correlation exists between management effectiveness score and surface area, percentage of professional staff in the total number of employees, and national protected area categorization. It is a surprising result that we have not found a statistically significant correlation between the protected area effectiveness and the density of rangers in the protected area. This should be subjected to further analysis. Regarding other elements, the results are as expected, since professional staff mostly contribute to performing the protected area management tasks, i.e., the higher the conservation level of a given protected area, it is expected that these protected areas have more strict and conservation implementation measures.

The results also indicated the absence of significant correlation between management effectiveness and IUCN categorization of the protected area. IUCN categories cannot be automatically transferred and implemented to the national level, but rather an analysis should be performed for each individual 
protected area. A similar pattern emerges in other countries since management is adjusted to already developed national systems [41], and not to the IUCN categories [17]. A recommendation is that the IUCN system implementation is used as a means of improving the national categorization system, as well as for management of protected areas in general [30].

Analysis as to which legal-organizational form of manager is the most effective to manage protected areas, from the point of view of primary activity performed by an individual manager, indicates that nature conservation, i.e., of environmental protection, as the primary activity is not the assumption that would make the manager more effective than others. Nevertheless, it is worth mentioning that within the group of six best ranked protected areas (Appendix A, Figure A1) in terms of management effectiveness, three of them are managed by a manager whose primary function is nature conservation. It can be stated that, if nature conservation is the primary activity of managers, it can be a significant, but not a determining fact.

In terms of the manager's organizational type and its impact on management effectiveness, the analysis indicates that the management effectiveness is somewhat better in the case of public enterprises. This is the case because, among other things, out of six highest-ranked protected areas (Appendix A, Figure A1), as many as four of them are managed by public enterprises meeting almost all legally prescribed criteria. Nevertheless, this aspect can serve no further purpose to formulate a more clear opinion, since the sample evaluated in this paper is not sufficiently representative for such purpose. One should point out the fact that public enterprises often put profit above the nature conservation. Lawmakers have clearly pointed out in Article 67 of the Law of Nature Conservation that protected areas management is of public interest. However, the majority of managers have dual function-as an one of economic user of the space for the purpose of realizing material and other gains, and as a responsible entity for the conservation and improvement of natural values. Natural value management operations in the function of protection and sustainable development can in no manner be misidentified with the operations, goals and aims of economic activities realized in various fields in the region, not even by managers. Even public enterprises in charge of certain national parks in the Republic of Serbia had to provide for certain funds for their operations through various activities, such as forestry, which often diverged from the primary function for which they were established [42].

Finally, the results interrelating minimal obligations stipulated by law and implementation of obligations in the field (Figure 4) indicate that the managers who met all three fundamental criteria (management plan, adequate professional staff, and ranger service) significantly better implement operational activities of conservation and the improvement of protected areas. These findings are completely in accordance with our research hypothesis.

The contribution of the conducted research is twofold. First, on the local level, it realistically shows the situation of the management in protected areas in Serbia, and, thus, should contribute to its improvement. Second, on the more general level, it proposes a novel assessment model that can be applied to similar protected areas. The results of the research confirm the importance of incorporating legally prescribed criteria into the preliminary assessment of the quality of nature conservation management.

\section{Conclusions}

This paper has set two basic objectives-to explore the fulfillment of the legally prescribed obligations that all managers in the Republic of Serbia are expected to meet, as well as to-based on the evidence at our disposal—assess and analyze management effectiveness in the protected areas.

The authors' conclusion is that about half of the protected areas have no adequate management in terms of the legally prescribed management criteria. Following the analysis of additional variables, they conclude that only two protected areas (NP Fruška Gora and Special Nature Reserve "Obedska bara") meet all the criteria. 
The results indicate that the effectiveness management score is greater with larger-sized protected areas with professional staff in greater numbers and protected areas with a more strict level of conservation, according to the national categorization of protected areas.

With respect to organizational and legal type of the protected area manager, the analyses have shown that the best result is accomplished with public companies as managers, although the existing sample is not sufficient to substantiate certain points of view more elaborately.

Bearing in mind all the stated elements, the authors conclude that meeting all the criteria stipulated by law and the existence of professional staff represents fundamental factors for the effective management of protected areas. This should be one of the key factors when individual legal entities are entrusted to manage protected areas, i.e., whether such entity possesses professional staff and what its capacities are, as well as the control of the fulfillment of legally prescribed obligations for protected area managers.

Author Contributions: Conceptualization, N.B. and R.M.; Data curation, K.D.; Formal analysis, J.I.; Investigation, N.B. and K.D.; Methodology, N.B. and K.D.; Project administration, N.B.; Resources, K.D.; Supervision, R.M.; Visualization, K.D.; Writing—original draft, N.B., K.D. and J.I.; Writing—review and editing, R.M. and J.I.

Funding: This research received no external funding.

Acknowledgments: The data was used with consent of Institute for Nature Conservation of Vojvodina Province. The authors thank anonymous referees for the valuable comments, and Andrew Salt and Ivan Filipović for the language revision.

Conflicts of Interest: The authors declare no conflict of interest.

\section{Appendix A}

Table A1. The list of managers and protected areas.

\begin{tabular}{|c|c|c|}
\hline No & Protected Area & Protected Area Manager \\
\hline 1. & National Park Fruška Gora & Public Enterprise “Nacionalni park Fruška Gora" \\
\hline 2. & Special Nature Reserve Gornje Podunavlje & \multirow{5}{*}{ Public Enterprise "Vojvodina šume" } \\
\hline 3. & Special Nature Reserve Koviljsko-Petrovaradinski Rit & \\
\hline 4. & Special Nature Reserve Bagremara & \\
\hline 5. & Special Nature Reserve Deliblatska Peščara & \\
\hline 6. & Special Nature Reserve Obedska bara & \\
\hline 7. & Special Nature Reserve Ludaško Jezero & \multirow{4}{*}{ Public Enterprise "Palić-Ludaš" } \\
\hline 8. & Special Nature Reserve Selevenjske Pustare & \\
\hline 9. & Landscape of Outstanding Feature Subotička Peščara & \\
\hline 10. & Nature Park Palić & \\
\hline 11. & Nature Park Jegrička & \multirow{2}{*}{$\begin{array}{l}\text { Public Water Management Enterprise } \\
\text { "VodeVojvodine" }\end{array}$} \\
\hline 12. & Nature Park Beljanska Bara & \\
\hline 13. & Landscape of Outstanding Feature Vršačke Planine & \multirow{2}{*}{ Public Enterprise “Varoš” } \\
\hline 14. & Protected Habitat Mali Vršački Rit & \\
\hline 15. & Special Nature Reserve Ritovi donjeg Potisja & Public Enterprise “Rezervati prirode Zrenjanina" \\
\hline 16. & Nature Park Stara Tisa Kod Bisernog Ostrva & Public Enterprise for Utility Services "Komunalac" \\
\hline 17. & Special Nature Reserve Karađorđevo & Military Institution "Morović" \\
\hline 18. & Special Nature Reserve Kraljevac & Sports Anglers' Association “Deliblatsko jezero" \\
\hline 19. & Special Nature Reserve Slano Kopovo & Hunters' Association "Novi Bečej" \\
\hline 20. & Special Nature Reserve Zasavica & Scouts' Association Sremska Mitrovica \\
\hline 21. & Special Nature Reserve Titelski Breg & Public Enterprise "Titelski breg" \\
\hline 22. & Special Nature Reserve Carska Bara & Fisheries Production "Ečka" a.d. \\
\hline 23. & Special Nature Reserve Pašnjaci Velike Droplje & Hunters' Association Lovačko udruženje "Perjanica" \\
\hline
\end{tabular}


Table A1. Cont.

\begin{tabular}{ccc}
\hline No & Protected Area & Protected Area Manager \\
\hline 24. & Nature Park Tikvara & $\begin{array}{c}\text { Public Enterprise Sports and recreational Center } \\
\text { "Tikvara” }\end{array}$ \\
\hline 25. & Nature Park Begečka Jama & DTD Ribarstvo d.o.o. \\
\hline 26. & Nature Park Ponjavica & $\begin{array}{c}\text { Public Water Management Enterprise “Tamiš Dunav" } \\
\text { d.o.o. }\end{array}$ \\
\hline 27. & Protected Habitat Bara Trskovača & Ruma Municipality Tourist Organization \\
\hline 28. & Special Nature Reserve Okanj Bara & Environment Conservation Association “Okanj” \\
\hline 29. & Nature Park Rusanda & Special Rehabilitation Hospital “Rusanda" \\
\hline 30. & Nature Park Kamaraš & $\begin{array}{c}\text { Citizens' Environment Conservation and Native } \\
\text { Land Study Association "Iringo" }\end{array}$ \\
\hline
\end{tabular}

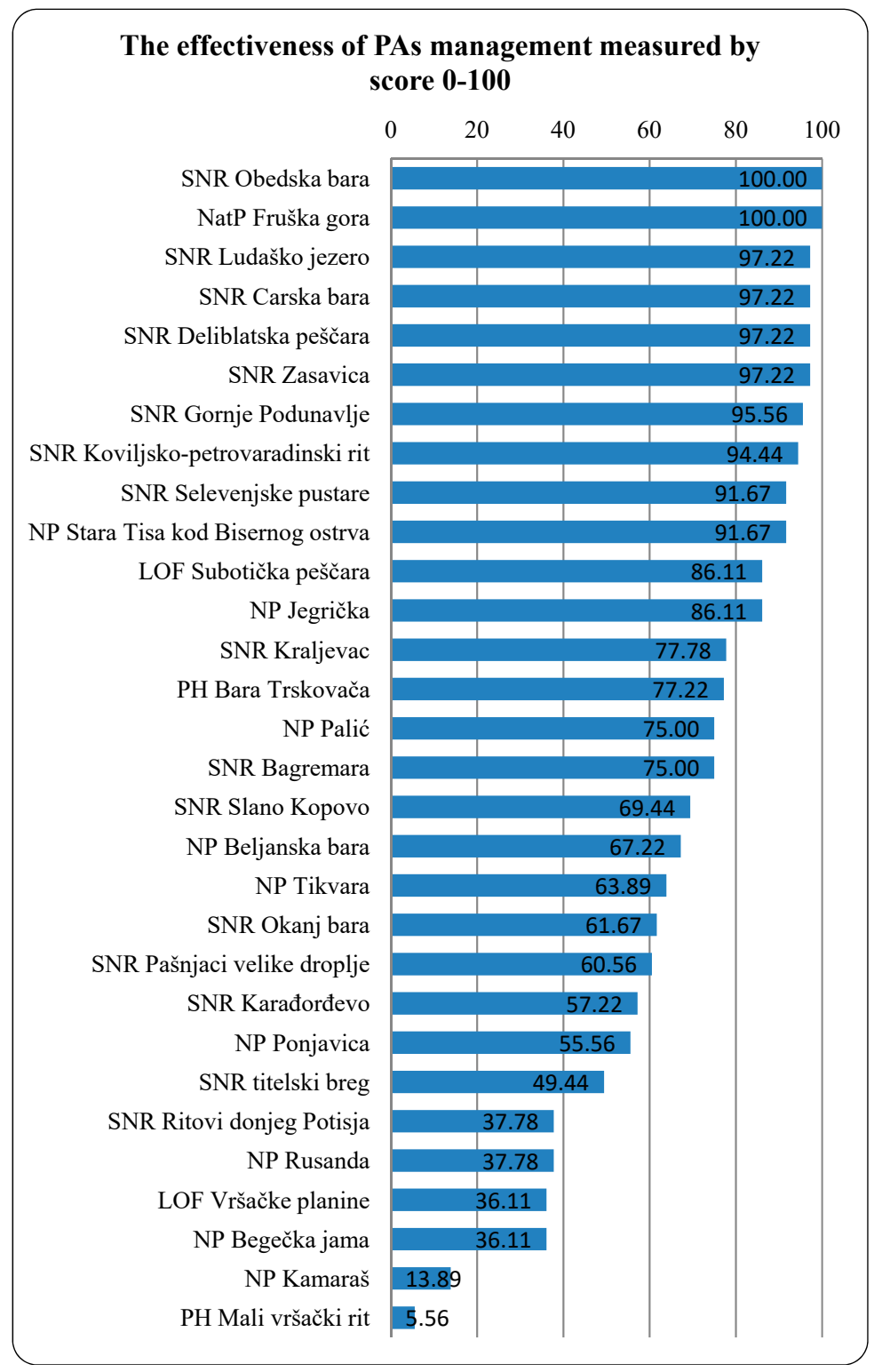

Figure A1. The assessment model results-Management Effectiveness Chart. 


\section{References}

1. Juffe-Bignoli, D.; Burgess, N.D.; Bingham, H.; Belle, E.M.S.; de Lima, M.G.; Deguignet, M.; Bertzky, B.; Milam, A.N.; Martinez-Lopez, J.; Lewis, E.; et al. Protected Planet Report 2014; UNEP-WCMC: Cambridge, UK, 2014.

2. Tittensor, D.P.; Walpole, M.; Hill, S.L.L.; Boyce, D.G.; Britten, G.L.; Burgess, N.D.; Butchart, S.H.M.; Leadley, P.W.; Regan, E.C.; Alkemade, R.; et al. A mid-term analysis of progress towards international biodiversity. Science 2014, 346, 241-244. [CrossRef] [PubMed]

3. Dirzo, R.; Young, H.S.; Galetti, M.; Ceballos, G.; Isaac, N.J.B.; Collen, B. Defaunation in the Anthropocene. Science 2014, 345, 401-406. [CrossRef] [PubMed]

4. Pimm, S.L.; Jenkins, C.N.; Abell, R.; Brooks, T.M.; Gittleman, J.L.; Joppa, L.N.; Raven, P.H.; Roberts, C.M.; Sexton, J.O. The biodiversity of species and their rates of extinction, distribution, and protection. Science 2014, 344, 987. [CrossRef] [PubMed]

5. Hockings, M.; Stolton, S.; Dudley, N. Management Effectiveness-Assessing management of protected areas. J. Environ. Pol. Plan. 2004, 6, 157-174. [CrossRef]

6. Dudley, N.; Stolton, S. (Eds.) Protected Area Management Effectiveness: METT; NORAD: Colorado Springs, CO, USA, 2009.

7. Pfleger, B. Evaluation of the Management Effectiveness of Central European Protected Areas-A Critical Revision of the Parks in Peril Site Consolidation Scorecard. Master's Thesis, University of Klagenfurt, Klagenfurt, Austria, 2007.

8. Hockings, M.; Philips, A. How well are we doing? Some thoughts on effectiveness of protected areas. Parks 1999, 9, 5-14.

9. Hockings, M.; Stolton, S.; Dudlez, N. Evaluating Effectiveness: A Framework for Assessing the Management of Protected Areas; IUCN: Gland, Switzerland; Cambridge, UK, 2009.

10. Ervin, J. Protected area assessment in perspective. BioScience 2003, 53, 819-822. [CrossRef]

11. Leverington, F.; Costa, K.L.; Courrau, J.; Pavese, H.; Nolte, C.; Marr, M.; Coad, L.; Burgess, N.; Bomhard, B.; Hockings, M. Management Effectiveness Evaluation in Protected Areas-A Global Study; The University of Queensland: Brisbane, Australia, 2010.

12. WWF. Management Effectiveness Tracking Tool. Reporting Progress at Protected Area Sites; WWF International: Gland, Switzerland, 2007; p. 22.

13. Ervin, J. WWF Rapid Assessment and Prioritization of Protected Area Management (RAPPAM) Methodology; WWF: Gland, Switzerland, 2003; p. 52.

14. Leverington, F.; Lemos Costa, K.; Pavese, H.; Lisle, A.; Hockings, M. A global analysis of protected area management effectiveness. Environ. Manag. 2010, 46, 685-698. [CrossRef] [PubMed]

15. Cifuentes, M.A.; Izurieta, A.V.; de Faira, H.H. Measuring Protected Area Management Effectiveness. Forest Innovation Project; WWF: Gland, Switzerland; IUCN: Gland, Switzerland; Cambridge, UK; GTZ: Turrialba, Costa Rica, 2000; p. 11.

16. Hockings, M.; Stolton, S.; Leverington, F.; Dudley, N.; Courrau, J. Evaluating Effectiveness: A Framework for Assessing Management Effectiveness of Protected Areas, 2nd ed.; IUCN: Gland, Switzerland; Cambridge, UK, 2006; p. 1.

17. Munoz, L.; Hausner, V.H. What Do the IUCN Categories Really Protect? A Case Study of the Alpine Regions in Spain. Sustainability 2013, 5, 2367-2388. [CrossRef]

18. Rand, M.; Spalding, M.; Sanjayan, M. Paper parks re-examines: Building a future for "MPAs-in-Waiting". MPA News 2012, 13, 1-3.

19. McNeely, J.A. Protected areas for the 21st century: Working to provide benefits to society. Biodivers. Conserv. 1994, 3, 390-405. [CrossRef]

20. Stoll-Kleemann, S.; Job, H. The Relevance of Effective Protected Areas for Biodiversity Conservation: An Introduction. GAIA 2008, 17, 86-89. [CrossRef]

21. Hockings, M. Systems for Assessing the Effectiveness of Management in Protected Areas. BioScience 2003, 53, 823-832. [CrossRef]

22. Mijović, A.; Sekulić, N.; Popović, S.; Stavretović, N.; Radović, I. Biodiversity of Serbia-State-of-the-Art and perspectives (in Serbian); Institute for Nature Conservation of Serbia: Belgrade, Serbia, 2012. 
23. Law on Nature Protection; no. 36/2009, 88/2010 and 91/2010-corr. and 14/2016; Official Gazette of RS: Belgrade, Serbia, 2016.

24. Coulter, M. Strategic Management in Action; Prentice Hall: Upper Saddle River, NJ, USA, 2008; p. 110.

25. Piscevic, N. Rapid Assessment and Prioritization of Protected Area Management (RAPPAM); Ministry of Environment and Spatial Planning of Republic of Serbia and WWF: Belgrade, Serbia, 2009.

26. Orlovic-Lovren, V. Capacity development for protected area management in Serbia- needs and opportunities. Andrag. Stud. 2009, 2, 139-148.

27. Stojnić, N.; Panjković, B.; Sabadoš, K. (Eds.) Report on the Nature Conditions in the Province of Vojvodina for 2010-2014 (in Serbian); Provincial Institute for Nature Conservation: Novi Sad, Serbia, 2015.

28. Nolte, C.; Leverington, F.; Kettner, A.; Marr, M.; Nielsen, G.; Bomhard, B.; Stolton, S.; Stoll-Kleemann, S.; Hockings, M. Protected Area Management Effectiveness Assessments in Europe. A Review of Application, Methods and Results; Ernst Moritz Arndt, Universität Greifswald: Greifswald, Germany; The University of Queensland: Brisbane, Australia; EUROPARC Federation: Regensburg, Germany; UNEP-WCMC: Cambridge, UK; WWF: Gland, Switzerland; Bundesamt für Naturschutz: Bonn, Germany, 2010.

29. Dudley, N. (Ed.) Guidelines for Applying Protected Area Management Categories; IUCN: Gland, Switzerland, 2008.

30. Sekulić, G. Overview of the National System of Protected Areas in Serbia: Recommendations for the Implementation of IUCN Protected Area Management Categories. Master's Thesis, Management of Protected Area's Programme, University of Klagenfurt, Klagenfurt, Austria, 2011.

31. Grujičić, I.; Milijić, V.; Nonić, D. Conflict management in protected areas: The Lazar Canyon natural monument, Eastern Serbia. Int. J. Biodivers. Sci. Manag. 2008, 4, 219-229. [CrossRef]

32. Puzović, S.; Panjković, B.; Tucakov, M.; Stojnić, N.; Sabadoš, K.; Stojanović, T.; Vig, L.; Marić, B.; Tešić, O.; Kiš, A.; et al. Natural Heritage Management in Vojvodina (in Serbian); Pokrajinski sekretarijat za urbanizam, graditeljstvo i zaštitu životne sredine i Pokrajinski zavod za zaštitu prirode: Novi Sad, Serbia, 2015.

33. Regulation on Designation and Protection of Strictly Protected and Protected Wild Species of Plants, Animals and Fungi; no. 5/2010 and 47/2011; Official Gazette of RS: Belgrade, Serbia, 2011.

34. Thomas, L.; Middleton, J. Guidelines for Management Planning of Protected Areas; IUCN: Gland, Switzerland; Cambridge, UK, 2003.

35. Regulation on Prerequisite Terms for the Managing Authority of Protected Area; no. 85/2009; Official Gazette of RS: Belgrade, Serbia, 2009.

36. Decision on Establishing the National Environment Protection Program; no. 12/2010; Official Gazette of RS: Belgrade, Serbia, 2010.

37. McCool, S.F. Constructing partnership for protected area tourism planning in an era of change and messiness. J. Sustain. Tour. 2009, 17, 1-16. [CrossRef]

38. Spenceley, A.; Kohl, J.; McArthur, S.; Myles, P.; Notarianni, M.; Paleczny, D.; Pickering, C.; Worboys, G.L. Visitor management. In Protected Area Governance and Management; Worboys, G.L., Lockwood, M., Kothari, A., Feary, S., Pulsford, I., Eds.; ANU Press: Canberra, Australia, 2015; pp. 715-750.

39. diMinin, E.; Toivonen, T. Global Protected Area Expansion: Creating More than Paper Parks. BioScience 2015, 65, 637-638. [CrossRef]

40. Lockwood, M. (Good governance for terrestrial protected areas: A framework, principles and performance outcomes. J. Environ. Manag. 2010, 91, 754-766. [CrossRef]

41. Hobbs, R.J.; Cole, D.N.; Yung, L.; Zavaleta, E.S.; Aplet, G.H.; Chapin, F.S.; Landres, P.B.; Parsons, D.J.; Stephenson, N.L.; White, P.S.; et al. Guiding concepts for park and wilderness stewardship in an era of global environmental change. Front. Ecol. Environ. 2010, 8, 483-490. [CrossRef]

42. Puzović, S. Conservation and management of protected areas in Serbia. Prot. Nat. 2008, 60, 17-26.

(C) 2019 by the authors. Licensee MDPI, Basel, Switzerland. This article is an open access article distributed under the terms and conditions of the Creative Commons Attribution (CC BY) license (http://creativecommons.org/licenses/by/4.0/). 